\title{
PEMELIHARAAN LARVA IKAN KLOWN (Amphiprion percula) DENGAN PAKAN ALAMI YANG BERBEDA
}

\author{
Ketut Maha Setiawati ${ }^{\#}$, Gunawan, dan Jhon Harianto Hutapea
}

Balai Besar Penelitian dan Pengembangan Budidaya Laut

\begin{abstract}
ABSTRAK
Nilai jual ikan hias klown sangat tergantung dari kecerahan dan keunikan warna yang dimilikinya, namun ikan hias produk hatcheri masih belum sebaik hasil tangkapan alam. Pengkayaan dengan bahan komersial dan Nannochloropsis sp. pada rotifer dan Artemia sebagai pakan alami tidak mampu meningkatkan kecerahan warna benih ikan. Oleh sebab itu, diperlukan pakan alami lain yang mampu meningkatkan kecerahan warna. Penelitian ini bertujuan untuk mengetahui pengaruh pemberian rotifer dan copepod terhadap performan warna benih ikan klown, serta pertumbuhan dan sintasan yang dihasilkan. Penelitian dilakukan dengan menggunakan wadah bak fiber volume $200 \mathrm{~L}$ yang diisi air laut sebanyak $150 \mathrm{~L}$. Telur ikan klown yang telah berumur enam hari ditebar sebanyak 200 butir/bak. Perlakuan berupa pemberian pakan alami: (A) rotifer dan (B) rotifer + copepod yang masing-masing mempunyai lima ulangan. Pemberian pakan perlakuan dilakukan sampai larva berumur 30 hari. Selain pakan perlakuan, mulai hari ke-20 juga ditambahkan pakan buatan berupa pakan mikro pada semua larva. Hasil penelitian menunjukkan bahwa, tambahan copepod sebagai pakan alami pada pemeliharaan larva ikan klown dapat meningkatkan kecerahan warna. Selain itu, panjang total dan bobot badan larva pada hari ke-20 untuk perlakuan B adalah masingmasing 10,44 $\pm 0,24 \mathrm{~mm}$ dan 15,2 $\pm 0,5 \mathrm{mg}$ lebih baik daripada perlakuan A yaitu 9,15 $\pm 1,27 \mathrm{~mm}$ dan $9,2 \pm 0,1 \mathrm{mg}$. Demikian pula vitalitas benih yang dihasilkan, menunjukkan bahwa ikan pada perlakuan B lebih kuat dibandingkan perlakuan A. Benih ikan pada perlakuan B tahan selama 231,6 detik dalam air tawar sedangkan pada perlakuan A hanya selama 39,8 detik.
\end{abstract}

KATA KUNCI: larva ikan klown; copepod; pertumbuhan; warna; vitalitas

ABSTRACT: Rearing of clownfish (Amphiprion percula) larvae with different live food. By: Ketut Maha Setiawati, Gunawan, and Jhon Harianto Hutapea

Price of ornamental fish highly depends on the brightness and unique appearance of its color. While of ornamental fish bred in hatcheries are less attractive in appearance compared to the wild ones. Enrichment of live feed i.e rotifer and Artemia using commercial enrichment and Nannochloropsis sp. was not able to improve the color brightness on the hatchery produced seed. Therefore, this research was designed to evaluate the use of other live feed such as copepod to improve color brightness, growth, survival rate, performance, and vitality of clownfish. Larvae used for this research were reared until day 30. The research was conducted using fiberglass tank of $200 \mathrm{~L}$ volume and filled with $150 \mathrm{~L}$ sea water. Six days eggs were used in the experiment. Eggs density was 200 ind./tank. Larvae were fed either rotifer (A) or rotifer $+\operatorname{copepod}(B)$ as treatment. Each treatment has five replicates. The results showed that total length and body weight of larvae in each treatment were $9.15 \pm 1.27 \mathrm{~mm}$ and $9.2 \pm 0.1 \mathrm{mg}$ for treatment $A$, and $10.44 \pm 0.24 \mathrm{~mm}$ and $15.2 \pm 0.5 \mathrm{mg}$ for treatment $B$. Visually, seed of treatment $B$ had brighter color than treatment $A$. Vitality test was performed by dipping the seed in fresh water. It showed that seed of treatment B survived for 231.6 seconds, which was longer compared to treatment A which was only survived for 39.8 seconds in fresh water. It can be concluded that addition of copepod as live food for clown fish larvae enhance its growth, color brightness and vitality.

KEYWORDS: clownfish larvae; copepods; growth; color brightness; vitality

\# Korespondensi: Balai Besar Penelitian dan Pengembangan Budidaya Laut. Jl. Br. Gondol Kec. Gerokgak Kab. Buleleng, Kotak Pos 140, Singaraja, Bali 81101, Indonesia.

Tel.: + (0362) 92272; 92271

E-mail: mahasetiawati@yahoo.com 


\section{PENDAHULUAN}

Nilai jual satu jenis ikan hias dapat berbeda-beda tergantung dari kecerahan dan keunikan warna yang dimilikinya. Sedangkan warna benih ikan hias klown hasil produk dari hatcheri masih berwarna pucat. Menurut Kumar \& Balasubramanian (2009), pada pemeliharaan larva ikan klown (Amphiprion ocellaris), pakan alami yang biasa diberikan adalah alga sebagai peneduh, serta rotifer dan naupli Artemia sebagai pakan awal.

Ikan klown termasuk ikan omnivora yaitu pemakan berbagai jenis makanan. Pakan alami yang biasa menjadi makanannya adalah jenis-jenis zooplankton udang kecil, cacing, dan alga. Hasil analisis isi lambung menunjukkan unsur hewani lebih banyak daripada unsur nabatinya (Allen, 1972). Setiawati et al. (2011a) dalam penelitiannya menemukan bahwa copepod merupakan pakan alami yang sering ditemukan pada ikan klown asli yang dipelihara di karamba jaring apung (KJA). Beberapa upaya untuk meningkatkan kualitas warna ikan klown di hatcheri telah dilakukan Setiawati et al. (2011b) baik dengan penambahan astaxanthin pada pakan buatan ataupun pemberian pakan alami. Hasil penelitian terdahulu yang menggunakan pengkayaan pakan alami dengan bahan komersial dan Nannochloropsis pada rotifer dan Artemia belum mampu meningkatkan kecerahan warna benih ikan (Setiawati \& Gunawan, 2013). Menurut Hansen (2011), bahwa pemberian pakan naupli copepod pada larva ikan cod menghasilkan pigmen warna larva yang lebih kuning daripada pemberian pakan kombinasi copepod dengan rotifer yang diperkaya, ataupun hanya rotifer yang diperkaya, serta rotifer yang dikultur dengan Chlorella. Pemberian pakan copepod juga menghasilkan pertumbuhan, sintasan, dan kualitas larva yang lebih baik daripada hanya pemberian pakan rotifer. Berdasarkan dua hal tersebut di atas, maka dilakukan penelitian untuk peningkatan kualitas benih ikan klown yang meliputi kualitas warna benih, pertumbuhan, sintasan, dan vitalitas benih yang dihasilkan.

\section{BAHAN DAN METODE}

Penelitian ini dilakukan di Balai Besar Penelitian dan Pengembangan Budidaya Laut, Gondol selama 30 hari. Sebagai wadah percobaan digunakan bak fiber volume $200 \mathrm{~L}$. Pada setiap dua bak (sebagai satu pasang ulangan dari masing-masing perlakuan) diisi masingmasing 200 butir telur ikan klown yang telah berumur enam hari dari satu pasang induk yang sama. Pada pasangan ulangan berikutnya sampai ulangan ke-5 juga digunakan telur masing-masing dari satu pasangan induk yang lain dengan kepadatan yang sama masingmasing 200 butir/bak. Setelah menetas, larva diberi pakan alami berbeda sesuai perlakuan, yaitu perlakuan
A) pakan rotifer dan B) pakan rotifer + copepod. Pemberian pakan sesuai perlakuan dilakukan 1-2 kali per hari sampai larva berumur 20 hari. Pada hari ke20 larva pada masing-masing unit percobaan dipindahkan ke akuarium sesuai perlakuan. Mulai hari ke-20 sampai hari ke-30 larva tetap diberikan pakan sesuai perlakuan dan masing-masing juga ditambahkan pakan buatan berupa pakan mikro. Jumlah copepod yang diberikan 1.000-2.000 ind./bak (10-20 ind./L). Sedangkan rotifer yang diberikan berkisar 4-10 ind./ $\mathrm{mL}$. Setiap perlakuan terdiri dari lima ulangan.

Copepod berasal dari hasil budidaya yang didominasi jenis cyclopoid dan sebagian kecil harpaktikoid. Copepod dikultur dengan menggunakan plankton Nannochloropsis sp. dan pakan buatan. Copepod dipanen setiap tiga hari dengan cara mengalirkan media kultur melalui selang plastik dan ditampung dengan plankton net.

Pergantian air dilakukan mulai hari ke-5 sebanyak $30 \%$, selanjutnya pergantian air dilakukan setiap hari sebanyak $50 \%-70 \%$.

Pertumbuhan, sintasan, dan warna benih (secara visual) diamati pada hari ke-20. Jenis dan jumlah pakan pada saluran cerna diamati secara berkala pada hari ke-5, 10, 15, dan 20. Sedangkan vitalitas benih diamati pada hari ke-30. Pengukuran vitalitas benih dilakukan dengan cara perendaman dengan air tawar. Waktu mulai perendaman sampai ikan terlihat mulai pasif (posisi miring di dasar bak) dihitung sebagai batas maksimum. Dalam kondisi miring tersebut ikan segera dipindahkan ke dalam bak yang telah berisi air laut dan diberi aerasi sampai benih pulih kembali dan dapat berenang. Data dihimpun secara tabulasi dan dianalisis secara deskriptif untuk masing-masing parameter dan analisis statistik dengan menggunakan uji t pada parameter sintasan dan pertumbuhan (panjang dan bobot) benih (Fowler et al., 1998).

\section{HASIL DAN BAHASAN}

\section{Sintasan dan Pertumbuhan Larva}

Hasil perhitungan sintasan dan pertumbuhan larva ikan klown hingga akhir penelitian disajikan dalam Tabel 1.

Sintasan larva ikan klown selama 20 hari pemeliharaan dengan perlakuan pemberian pakan berupa rotifer (A) dan kombinasi copepod dan rotifer (B) tidak berbeda nyata $(\mathrm{P}>0,05)$. Ada permasalahan dalam pemeliharaan larva ini, di mana sintasan larva antar ulangan sangat bervariasi sehingga dalam pengujian statistik memberikan hasil yang tidak berbeda nyata. Hal ini disebabkan karena telur yang digunakan berasal dari pasangan induk yang sama pada 
Tabel 1. Rerata sintasan, panjang total dan bobot badan larva ikan klown, Amphiprion percula selama 20 hari pemeliharaan

Table 1. The average of total length, body weight of clownfish larvae during 20 days rearing

\begin{tabular}{|c|c|c|c|c|}
\hline \multicolumn{2}{|c|}{$\begin{array}{l}\text { Perlakuan } \\
\text { Treatments }\end{array}$} & $\begin{array}{c}\text { Sintasan } \\
\text { Survival rate (\%) }\end{array}$ & $\begin{array}{c}\text { Panjang total } \\
\text { Total length }(\mathrm{mm})\end{array}$ & $\begin{array}{c}\text { Bobot badan } \\
\text { Body weight (mg) }\end{array}$ \\
\hline \multicolumn{2}{|c|}{ Rotifer (A) } & $27.1 \pm 25.9^{\mathrm{a}}$ & $9.15 \pm 1.27^{\mathrm{a}}$ & $9.2 \pm 0.1^{\mathrm{a}}$ \\
\hline \multicolumn{2}{|c|}{ Copepod + Rotifer (B) } & $27.0 \pm 14.1^{\mathrm{a}}$ & $10.44 \pm 0.24^{\mathrm{b}}$ & $15.2 \pm 0.5^{\mathrm{b}}$ \\
\hline Keterangan: & Angka yang di & huruf (notasi) y & $\begin{array}{l}\text { ng sama pada kolom yar } \\
\text { a }(\mathrm{P}>0,05)\end{array}$ & ng sama menunjukkan \\
\hline Note: & $\begin{array}{l}\text { Value in the sam } \\
(P>0.05)\end{array}$ & e column followed by $t$ & he same letter are not sigi & ificantly different \\
\hline
\end{tabular}

satu ulangan dan ulangan berikutnya induk yang berbeda sehingga kualitas telur yang dihasilkan juga berbeda pada setiap ulangan. Berdasarkan analisis kualitas air, ternyata salinitas air laut yang digunakan relatif tinggi sebesar 33-34 ppt. Fluktuasi suhu air pemeliharaan larva juga cukup tinggi $26^{\circ} \mathrm{C}-28^{\circ} \mathrm{C}$. Hal ini juga diduga merupakan salah satu penyebab sintasan yang bervariasi pada masing-masing ulangan. Namun karena pada kedua perlakuan tersebut terjadi hal yang sama maka dapat disimpulkan bahwa baik pemberian pakan berupa rotifer ataupun kombinasi copepod dengan rotifer memberikan sintasan yang sama pada benih ikan klown.

Panjang total maupun bobot badan benih ikan klown pada akhir penelitian menunjukkan bahwa perlakuan B lebih tinggi $(10,44 \pm 0,24 \mathrm{~mm} ; 15,2 \pm$ $0,5 \mathrm{mg})$ dan berbeda nyata dengan perlakuan A $(9,15$ $\pm 1,27 \mathrm{~mm} ; 9,2 \pm 0,1 \mathrm{mg})$. Hal ini menunjukkan bahwa dengan pemberian copepod + rotifer (B) sebagai pakan dalam pemeliharaan larva hingga benih ikan klown, dapat memberikan pertumbuhan yang lebih baik dibandingkan dengan hanya memberikan pakan berupa rotifer. Hal yang sama ditemukan pada larva ikan dhufish (Glaucosoma hebraicum) dengan pemberian pakan berupa campuran 50\% naupli copepod dan 50\% rotifer mulai hari ke-2 menghasilkan pertumbuhan larva lebih cepat dibandingkan dengan yang hanya diberi pakan berupa rotifer. Demikian pula dengan larva pink snapper (Pagrus auratus) yang diberi pakan naupli copepod mulai umur empat hingga10 hari (Payne et al., 2001).

\section{Analisis Isi Lambung Larva}

Hasil pengamatan terhadap isi saluran cerna (Tabel 2) pada perlakuan B menunjukkan bahwa larva umur lima hari telah dapat memakan copepod sejumlah 3,2 $\pm 4,2$ ind./larva dan rotifer $0,57 \pm 1,13$ ind./larva. Sedangkan pada perlakuan A jumlah rotifer dalam saluran cerna mencapai130,3 \pm 46,4 ind./larva. Jumlah rotifer yang dimakan larva pada perlakuan A jauh lebih banyak dibandingkan jumlah copepod dan rotifer yang dimakan larva pada perlakuan B. Mengacu pada teori pemangsaan yang mengasumsikan bahwa jumlah pakan yang dibutuhkan berdasarkan kebutuhan energi yang diperlukan. Berarti untuk mendapatkan energi yang cukup, larva ikan klown harus memangsa lebih banyak rotifer. Sebaliknya untuk mendapatkan energi yang sama hanya dibutuhkan beberapa ekor copepod. Berdasarkan data tersebut dapat diasumsikan bahwa untuk mendapatkan jumlah pakan yang optimum, benih ikan pada perlakuan A membutuhkan waktu lebih banyak untuk memangsa rotifer daripada untuk memangsa copepod. Sehingga energi yang diperoleh dari rotifer, sebagian besar dikompensasikan untuk menangkap rotifer dan untuk bertahan hidup, yang mana hal itu tidak cukup mendukung pertumbuhan yang optimum. Dengan demikian, pilihan pakan terbaik adalah copepod ditambah rotifer daripada rotifer saja. Selain itu, diketahui bahwa ukuran copepod juga bervariasi. Naupli copepod yang baru menetas berukuran panjang 50-60 ìm, lebar 40-45 ìm; stadia naupli berukuran 50-180 ìm, fase kopepodit berukuran 190-500 ìm, dan copepod dewasa berukuran 500-600 ìm (Gopakumar \& Santhosi, 2009). Dengan kisaran ukuran tersebut copepod dapat dimanfaatkan sebagai pakan larva ikan klown mulai stadia awal hingga mencapai ukuran benih.

\section{Vitalitas Benih}

Perubahan suhu secara tiba-tiba, salinitas, dan penanganan (expose di udara) umumnya digunakan untuk mengetahui respons larva terhadap stres dan mortalitas merupakan pengaruh tersier dari stres yang diberikan (Barton, 2002). Ketahanan benih ikan klown terhadap perendaman dengan air tawar menunjukkan bahwa benih yang diberi perlakuan pakan rotifer + copepod menghasilkan vitalitas yang lebih tinggi yaitu dapat bertahan selama 231,6 detik dalam air tawar 
Tabel 2. Rerata jumlah dan jenis pakan alami yang terdapat pada saluran cerna larva ikan klown, Amphiprion percula pada masing-masing perlakuan yang diamati dengan interval waktu lima hari

Table 2. The average of live food in stomach content of clownfish, Amphiprion percula larvae in each treatment which was observed in five day intervals

\begin{tabular}{|c|c|c|c|c|c|}
\hline \multirow{3}{*}{$\begin{array}{c}\text { Umur larva (hari) } \\
\text { Age (days) }\end{array}$} & \multicolumn{5}{|c|}{ Perlakuan (Treatments) } \\
\hline & \multicolumn{2}{|c|}{$\begin{array}{l}\text { Rotifer (ind.) } \\
\text { (A) }\end{array}$} & \multicolumn{3}{|c|}{$\begin{array}{l}\text { Copepod dan rotifer (ind.) } \\
\text { (B) }\end{array}$} \\
\hline & Rotifer & Telur rotifer (Eggs) & Copepod & Naupli & Rotifer \\
\hline$d-5$ & $130.3 \pm 46.4$ & $31.0 \pm 8.3$ & $3.2 \pm 4.2$ & $1 \pm 1$ & $0.57 \pm 1.13$ \\
\hline$d-10$ & $265.0 \pm 66.1$ & $162.5 \pm 35$ & $12.3 \pm 11.4$ & $4 \pm 1$ & $12.7 \pm 11.7$ \\
\hline$d-15$ & $277.5 \pm 26.3$ & $101.3 \pm 18.4$ & $29.8 \pm 9.5$ & $11.0 \pm 6.6$ & $20.0 \pm 11.5$ \\
\hline$d-20$ & $>300$ & * & $26.0 \pm 22.4$ & $4.5 \pm 4.2$ & $88.8 \pm 77.5$ \\
\hline
\end{tabular}

Keterangan (Note): * tidak dihitung (not counted)

dibandingkan dengan benih yang diberi perlakuan pakan rotifer saja hanya bertahan selama 39,8 detik dalam air tawar (Tabel 3).

Hasil uji vitalitas menunjukkan bahwa benih yang diberi pakan copepod + rotifer (B) mempunyai vitalitas yang lebih baik. Hal ini terlihat dari uji ketahanan ketika benih ikan direndam dalam air tawar yang rata-rata mampu bertahan selama 231 detik dibandingkan dengan perlakuan rotifer (A) yang hanya dapat bertahan sekitar 40 detik. Hal ini menunjukkan bahwa pemberian copepod pada pemeliharaan larva ikan klown dapat meningkatkan vitalitas benih yang dihasilkan.

\section{Kecerahan Warna}

Warna yang dihasilkan menunjukkan bahwa dengan pemberian copepod memberikan warna yang jauh lebih cerah daripada diberi pakan berupa rotifer saja (Gambar 1).

Hansen (2011) melaporkan penggunaan naupli copepod (Acartia tonsa) sebagai pakan untuk larva ikan cod memberikan pigmen warna yang lebih kuning dibandingkan dengan pemberian pakan campuran copepod dengan rotifer yang diperkaya ataupun dengan hanya pemberian rotifer yang diperkaya. Pemberian pakan naupli copepod dalam pemeliharaan larva ikan secara intensif memberikan pertumbuhan dan sintasan yang lebih baik.

Ada tiga faktor utama yang dapat memengaruhi penampilan warna pada ikan budidaya yaitu faktor lingkungan baik kimia maupun fisika yang berpengaruh terhadap stres (Ruangpanit, 1993), kondisi nutrisi yang terkandung dalam pakan terutama beta-karoten (Suwirya et al., 2006) dan ekspresi gen pengatur kemunculan pigmentasi (Gouveia et al., 2003).

Copepod mempunyai kandungan karotenoid yang lebih tinggi (630-750 mg/kg bobot kering) daripada rotifer yang diperkaya dengan ragi roti dan minyak hati ikan cod; ragi roti dan algamac; ragi roti dan Chlorella, dan pengkaya Selco, dengan kandungan karotenoid berkisar antara $4-15 \mathrm{mg} / \mathrm{kg}$ bobot kering. Ternyata nutrisi pengkaya komersial seperti algamac mempunyai karotenoid yang jauh lebih rendah dari copepod. Kandungan vitamin C pada copepod mencapai

Tabel 3. Rerata nilai vitalitas benih ikan klown, Amphiprion percula pada perendaman dengan air tawar

Table 3. The average vitality of clownfish seed by dipping infresh water

\begin{tabular}{|c|c|}
\hline $\begin{array}{l}\text { Perlakuan } \\
\text { Treatments }\end{array}$ & $\begin{array}{c}\text { Vitalitas (detik) } \\
\text { Vitality (second) }\end{array}$ \\
\hline Rotifer (A) & $39.8 \pm 7.2$ \\
\hline Rotifer + Copepod (B) & $231.6 \pm 33.8$ \\
\hline
\end{tabular}




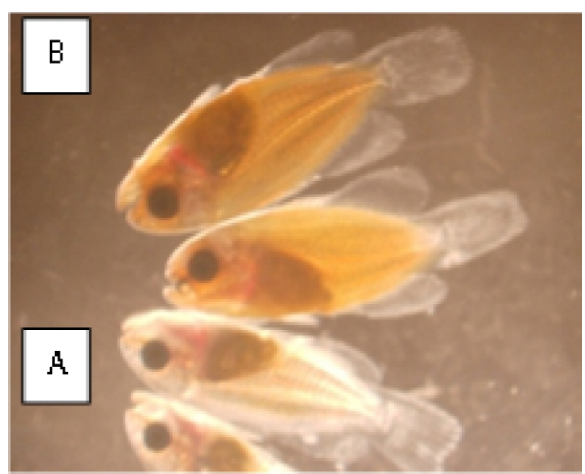

Gambar 1. Benih ikan klown, Amphiprion percula yang dihasilkan dari perlakuan A dan B

Figure 1. Seed of clownfish from treatment $A$ and $B$

$500 \mathrm{mg} / \mathrm{kg}$ bobot kering sedangkan pada rotifer yang diperkaya dengan Chlorella hanya $117 \pm 68 \mathrm{mg} / \mathrm{kg}$ bobot kering (Hamre et al., 2008). Pemberian pakan berupa copepod pada pemeliharaan benih ikan klown (A. ocellaris) memberikan warna lebih kemerahan, sedangkan pada pemberian pakan berupa rotifer, warna ikan menjadi orange kekuningan (Setiawati et al., 2008). Bahkan Aslianti \& Nasukha (2012) mendapatkan bahwa peningkatan kandungan karoten dalam pakan dapat meningkatkan pigmen merah dan kecerahan pada benih ikan kakap merah (Lutjanus sebae). Aliah et al. (2010) memberikan pakan Oithona sp. pada larva ikan kerapu bebek mulai hari ke-12 sebagai pengganti rotifer dan Artemia, menunjukkan bahwa pada umur 25 hari sintasan larva yang diberi pakan copepod tidak berbeda nyata dengan pemberian jenis pakan alami yang lain. Menurut Cutts (2003), copepod yang umumnya digunakan untuk budidaya adalah dari jenis Calanoid (Acartia sp., Clausocalnaus sp., Eurytemora sp., Calanus sp., Pseudocalanus sp., Gladioferens sp.), Cyclopoid (Apocyclops sp., Oithona sp.), dan Harpacatcoid (Tisbe sp., Tigriopus sp., Tisbenta sp., Schizopera sp., Euterpina sp.).

Ada beberapa jenis bahan pewarna yang dikenal dengan karoten di alam, namun jenis karoten yang paling efektif dan dominan untuk pewarna pada ikan adalah karoten dari jenis astaxanthin. Berdasarkan sumbernya, astaxanthin dibagi atas dua bagian yakni: astaxanthin alami (natural astaxanthin) dan astaxanthin buatan (synthetic astaxanthin) (Kurnia, 2010). Dibanding jenis karoten lain seperti beta-karoten atau cantaxanthin, astaxanthin menunjukkan pengaruh yang dominan dalam pewarnaan ikan budidaya.

Suwirya et al. (2006) menyatakan bahwa pakan yang tidak cukup mengandung karotenoid dapat menurunkan performansi benih ikan menjadi pucat. Sementara Gouveia et al. (2003) menyatakan bahwa ekspresi pigmen beta-karoten yang terkandung dalam daging atau kulit ikan merupakan komponen biologi pembentuk warna merah pada ikan. Astaxantin merupakan bahan utama karotenoid sebagai pembentuk pigmen merah pada ikan dan udang (Regunathan, 2008). Namun umumnya hewan-hewan akuatik tidak dapat mensintesis astaxanthin oleh karenanya harus ditambahkan dalam ransum pakan (Anonymous, 1999). Bahan sintetis asthin dan charophylpink dapat digunakan sebagai sumber karotenoid dalam ransum pakan benih kakap merah sehingga performansi warna benih dapat ditingkatkan menjadi berwarna merah dan lebih cerah (Aslianti et al., 2011). Pada ikan klown Premnas biaculeatus pemberian esterified astaxanthin sebanyak $214 \mathrm{mg} / \mathrm{L}$ selama 115 hari dapat memberikan warna yang cukup untuk nilai jual yang tinggi (Adeljean \& Lin, 2011). Begitu juga menurut (Yasir \& Qin, 2010), pemberian astaxanthin mempunyai potensi untuk meningkatkan kecerahan warna merah pada ikan klown biasa $(A$. ocellaris).

Kualitas air selama penelitian yang terdiri dari suhu berkisar $26^{\circ} \mathrm{C}-28^{\circ} \mathrm{C}$, salinitas $33-34 \mathrm{ppt}$, dan $\mathrm{pH} 8,4-$ 8,5 . Berdasar hasil tersebut terlihat bahwa kualitas air dalam penelitian ini masih mendukung kehidupan ikan klown.

\section{KESIMPULAN}

Pemberian pakan kombinasi rotifer dan copepod sebagai pakan alami pada pemeliharaan larva ikan klown Amphiprion percula, dapat meningkatkan pertumbuhan, kecerahan warna, vitalitas benih yang lebih baik daripada pemeliharaan dengan pemberian rotifer saja.

\section{UCAPAN TERIMA KASIH}

Terima kasih disampaikan kepada Kurdi, teknisi litkayasa bidang pakan alami yang telah membantu penyediaan copepod, Saudara Nyoman Restiada dan 
Feri Priatna untuk penyediaan Nannochloropsis sp., Saudara Muhdiat dan Kadek Ardika untuk penyediaan rotifer, Kadek Wijana untuk pemeliharaan larva. Ir. Titiek Aslianti M.P. dan Drs. Bedjo Slamet, M.Si. atas perbaikan terhadap penulisan makalah ini.

\section{DAFTAR ACUAN}

Adeljean, L.F.C.H., \& Lin, J. (2011). Effect of dietary esterified astaxanthin concentration on dermal coloration and chromatophore physiology in spinecheek anemonefish Premnas biaculeatus. World Aquaculture. (https://www.was.org/ Wa s M e e ting s/m e e ting s/mobile/ MG_Paper.aspx?i=24157).

Allen, G.P. (1972). The anemone fish. Their Classification and Biology. T.F.H. Publication Inc. Ltd., 288 pp.

Anonymous. (1999). Carophyll Pink.The proven source of astaxanthin for aquaculture. F. Hoffmann-La Roche Ltd. (http://www.roche.com).

Aliah, R.S., Kusmiyati, \& Yaniharto, D. (2010). Pemanfaatan copepoda Oithona sp. sebagai pakan hidup larva ikan kerapu. Jurnal Sains dan Teknologi Indonesia, 12(1), 45-52.

Aslianti, T., Nasukha, A., \& Priyono, A. (2011). Ekspresi beberapa jenis bahan karotenoid dalam pakan pada performansi warna benih ikan kakap merah (Lutjanus sebae). Berk. Penel. Hayati Edisi Khusus, 4, 51-57.

Aslianti, T., \& Nasukha, A. (2012). Peningkatan kualitas warna benih ikan kakap merah Lutjanus sebae melalui pakan yang diperkaya dengan minyak buah merah Pandanus conoideus sebagai sumber betakaroten. Jurnal Ilmu dan Teknologi Kelautan Tropis, 4(2), 171-178.

Barton, B.A. (2002). Stress in fishes: A diversity of responses with particular reference to changes in circulating corticosteroids 1 . Integ. and comp. Biol., 42, 517-525.

Cutts, C.J. (2003). Culture of harpacticoid copepods: potential as live feed for rearing marine fish. $A d v$. Mar. Biol., 44, 295-316.

Fowler, J., Cohen, L., \& Jarvis, P. (1998). Practical statistics for field biology. Second Edition. John Wiley \& Sons.Chichester, New York, Weinheim, Brisbane, Singapore and Toronto, 593 pp.

Gopakumar, G. \& Santhosi, I. (2009). Use of copepods aslive feed for larviculture of damsefishes. Asian Fisheries Science, 22, 1-6.

Gouveia, L., Rema, P., Pereira, O., \& Empis, J. (2003). Coloring ornamental fish (Cyprinus carpio and Carassius auratus) with microalgal biomass. Aquaculture nutrition, 9, 123-129.
Hamre, K., Srivastava, A., Rønnestad, I., MangorJensen, A., \& Stoss, J. (2008). Several micronutrients in the rotifer Brachionus sp. may not fulfill the nutritional requirements of marine fish larvae. Aquaculture Nutrition, 14, 51-60.

Hansen, M.H. (2011). Effects of feeding with copepod nauplii (Acartia tonsa) compared to rotifers (Brachionus ibericus, Cayman) on quality parameters in Atlantic cod (Gadus morhua) larvae. Norwegian University of Science and Technology, Department of Biology. Norway, 120 pp.

Kumar, T.T.A., \& Balasubramanian, T. (2009). Broodstock development, spawning and larval rearing of the false clownfish, Amphiprion ocellaris in captivity using estuarine water. Current Science, 97(10), 1483-1486.

Kurnia, A. (2010). Lebih jauh tentang bahan pewarna ikan. (http://www.unila.ac.id/index.php/en/home$\mathrm{m}$ a i n m e n u - 1/72-arsi p/538Lebih\%20 Ja u $\% 20$ Tentang $\% 20$ Bahan $\% 20$ Pewarna\%20Ikan).

Payne, M.F., Rippingale, R.J., \& Cleary, J.J. (2001). Cultured copepods as food for West Australian dhufish (Glaucosoma hebraicum) and pink snapper (Pagrus auratus) larvae. Aquaculture, 194, 137-150.

Ruangpanit, N. (1993). Technical manual for seed production of grouper (Epinephelus malabaricus). National Institute of Coastal Aquaculture (NICA), Department of Fisheries, Ministry of Agriculture \& Cooperatives. Thailand, 46 pp.

Setiawati, K.M., Kusumawati, D., \& Imanto, P.T. (2008). Peningkatan warna juwana ikan klon ( $A$. ocellaris) dengan pakan alami. Prosiding Seminar Nasional Perikanan dan Kelautan Bidang Budidaya Perairan. Fakultas Perikanan dan Kelautan, Universitas Brawijaya. Malang, hlm. 148-150.

Setiawati, K.M., Gunawan, Yudha, H.T.Y., Hutapea, J.H., \& Suarsana, K. (2011a). Pengaruh shelter pada pemeliharaan benih ikan klon biak (Amphiprion percula) di karamba jaring apung. Forum Inovasi Teknologi Akuakultur, hlm. 79-85.

Setiawati, K.M., Kusumawati, D., Hutapea, J.H., Boer, D.R., Giri, N.A., Wardoyo, Suarsana, K., \& Widnyana, P. (2011b). Petunjuk teknis perbenihan ikan hias klon (Amphiprion ocellaris dan Amphiprion percula). Balai Besar Penelitian dan Pengembangan Budidaya Laut. $44 \mathrm{hlm}$.

Setiawati, K.M., \& Gunawan. (2013). Pemeliharaan ikan hias balong padang (Premnas biaculeatus) dengan pengkayaan pakan alami. Jurnal Ilmu dan Teknologi Kelautan Tropis, 3(1), 47-53.

Suwirya, K., Priyono, A., Hanafi, A., Andamari, R., Melianawati, R., Marzuqi, M., Sugama K., \& Giri, 
N.A. (2006). Pedoman teknis pembenihan ikan kerapu sunu (Plectropomus leopardus). Pusat Riset Perikanan Budidaya. Badan Riset Kelautan dan Perikanan. Jakarta, $18 \mathrm{hlm}$.

Regunathan. (2008). Review: Carotenoids in shrimp maturationand larval quality. Aquaculture. Asia Pacific Magazine, 4(6), 18-20.

Yasir, I., \& Qin, J.G. (2010). Effect of dietary carotenoids on skin color and pigments of false clownfish, Amphiprion ocellaris, Cuvier.Journal of the World Aquaculture Society, 41, 308-318. 